\title{
BURDEN OF TEENAGE PREGNANCIES IN HILLY AREA OF EASTERN REGION OF NEPAL
}

\section{Ram Bilakshan Sah, Kumar Gaurav, Dharani Dhar Baral, Nilambar Jha and Paras Kumar Pokharel}

\begin{abstract}
Teenage pregnancy, which is detrimental to the health of mother and child, is a common public health problem worldwide. It is a problem that affects nearly every society- developed and developing alike. The objective of this study was to find out the prevalence of teenage pregnancy and its impact on birth outcome.The cross-sectional study was conducted among the residents of Dhankuta municipality where 246 households were taken as subjects. Chi-square test was applied to find out the significant difference between sociodemographic characteristics and outcome variable i.e. birth outcome \& age of $1^{\text {st }}$ pregnancy. About $34.6 \%$ of respondents were pregnant at below 20 years of age.The teenage pregnancies decreases as education level increases $(p<0.001)$. Furthermore, economic variable shows stronger association with teenage pregnancies $(\mathrm{p}<0.001)$. Fetal complication was significantly higher among below 20 years of age (81\%) than women with 20 years and above (19\%). The proportion of low birth weight $(<2.5 \mathrm{~kg})$ babies was also significantly higher in women with teenage pregnancy (78.3\%) than women with 20 years and above (21.7\%). We conclude that the problem of teenage pregnancy is common and has become a key public health concern for all. The teenage pregnancy was not favourable condition for baby outcome.
\end{abstract}

Keywords: Teenage pregnancies; Hilly area; Birth outcome; Nepal

\section{Introduction}

The adolescent period covers the age of 10-19 years. ${ }^{1}$ Adolescent pregnancy continues to be a complex and challenging issue for families, health workers, educators, societies and governments, and adolescents themselves. ${ }^{2}$ One of the important factors for the rapid population growth in the world is adolescent childbearing. ${ }^{3}$ United Nations also remarks that early child bearing is a high health risk for both mother and child. ${ }^{4}$

A significant and considerable number of women get married and bear child in their teenage in Nepal but they are not equally distributed across urban and rural areas and exact data are not available. Adolescents comprise of $23 \%$ of 23 millions of Nepalese population. ${ }^{5}$ The median age at first marriage for ever married women in Nepal (age 15-49) is 16.6 years, which indicates that majority of newly married couples are adolescents. ${ }^{6}$

The children of teenage mothers are at greater risk of lower intellectual and academic achievement, health complications, social behavior problems and problems of selfcontrol than are children of older mothers, primarily due to the effects of single parenthood, lower maternal education, and large family size. Teenage mothers have a higher incidence of low birth babies. These babies are usually associated with birth injuries, serious childhood illness and mental and physical disabilities. Birth weight is 
strongly associated with infant mortality; mortality went on decreasing with better birth weight. $^{7}$ Therefore, This study was designed to find out the prevalence of teenage pregnancy and its impact on birth outcome.

\section{Material and methods}

The cross-sectional study was conducted from $28^{\text {th }}$ March to $10^{\text {th }}$ April, 2013 among the residents of Dhankuta municipality in Eastern Nepal. Among 9 wards, the ward number 4 was randomly selected by lottery method in Dhankuta Municipality.To represent the women for $62 \%$ Teenage pregnancy (Alehagen SA et al in 2012) sample size calculated was 246. All the participants aged 15 to 49 years from the selected households were included in the study. Convenient purposive sampling technique was applied for data collection.

A written permission was taken from concerned authority and an informed verbal consent was taken from the participants of the study. Those families which were available after three visits and willing to give verbal consents were included in the study. Pretested semi-structured questionnaire was administered to the study subjects in the presence of investigator and face to face interview was conducted.

The collected data was entered in MS Excel 2000. The analysis was done by using statistical software SPSS (Statistical Package for Social Science) 17.0 version. Chi-square test was applied to find out the significant difference between sociodemographic characteristics and outcome variable i.e. birth outcome \& age of $1^{\text {st }}$ pregnancy. The probability of occurrence by chance is significant if $\mathrm{P}<0.05$ with 95\% Confidence Interval.
Table 1. Study population by different sociodemographic characteristics

\begin{tabular}{|l|c|c|}
\hline \multicolumn{1}{|c|}{ Characteristics } & Frequency & Percent \\
\hline Age of $1^{\text {st }}$ pregnancy & & \\
Below 20 years & 85 & 34.6 \\
20 years \& above & 161 & 65.4 \\
\hline Religion & 227 & 92.3 \\
Hindu & 19 & 7.7 \\
Others (Buddhist, & & \\
Christian) & & \\
\hline Ethnicity & 96 & 39.0 \\
Brahmin/ Chhetri & 125 & 50.8 \\
Janajati/ Kirati & 25 & 10.2 \\
Others (Dalit, Terai & & \\
caste) & 39 & 15.9 \\
\hline Education of wife & 99 & 40.2 \\
Illiterate & 108 & 43.9 \\
Below SLC & & \\
SLC and above & 9 & 3.7 \\
\hline Education of husband & 102 & 41.4 \\
Illiterate & 135 & 54.9 \\
Below SLC & & \\
SLC and above & 101 & 41.1 \\
\hline Economic status & 145 & 58.9 \\
Below poverty & & \\
line(<1.25 US\$) & & \\
Above poverty line & & 56.1 \\
( $\geq 1.25$ US \$) & & 100.0 \\
\hline $1^{\text {st }}$ pregnancy & & \\
Planned & & \\
Unplanned & & \\
\hline Total & & \\
\hline
\end{tabular}

About thirty five percent of women were pregnant at below 20 years of age (Teenage pregnancy) and nearly forty four percent were unplanned pregnincies. Study population showed high level of Janajati and Kirati ethnic group (50.8\%) followed by Brahmin/Chhetri (39\%), and Others including Dalit and Terai caste (10.2\%). Regarding education of wife, almost forty four percent of the women had completed SLC and higher education, forty percent had below SLC and sixteen percent were still illiterate.

\section{Result}


Table 2. Association between selected variables with age of $1^{\text {st }}$ pregnancy

\begin{tabular}{|l|c|c|c|c|}
\hline \multicolumn{1}{|c|}{ Characteristics } & Below 20 years & 20 years \& above & Total & P- value \\
\hline Religion & & & & \\
Hindu & $78(34.4)$ & $149(65.6)$ & 227 & 0.827 \\
Others (Buddhist, Christian) & $7(36.8)$ & $12(63.2)$ & 19 & \\
\hline Ethnicity & $26(27.1)$ & $70(72.9)$ & 96 & 0.016 \\
Brahmin/ Chhetri & $46(36.8)$ & $79(63.2)$ & 125 & \\
Janajati/Kirati & $13(52.0)$ & $12(48.0)$ & 25 & \\
Others (Dalit, Terai caste) & $28(71.8)$ & $11(28.2)$ & 39 & $<0.001$ \\
\hline Education of wife & $34(34.3)$ & $65(65.7)$ & 99 & \\
Illiterate & $23(21.3)$ & $85(78.7)$ & 108 & \\
Below SLC & $6(66.7)$ & $3(33.3)$ & 9 & $<0.001$ \\
SLC and above & $49(48.0)$ & $53(52.0)$ & 102 & \\
\hline Education of husband & $30(22.2)$ & $105(77.8)$ & 135 & \\
Illiterate & & & & \\
Below SLC & $77(76.2)$ & $24(23.8)$ & 101 & $<0.001$ \\
SLC and above & $8(5.5)$ & $137(94.5)$ & 145 & \\
\hline Economic status & $35(25.4)$ & $103(74.6)$ & 138 & $<0.001$ \\
Below poverty line(<1.25 US\$) & $50(46.3)$ & $58(53.7)$ & 108 & \\
Above poverty line $(\geq 1.25$ US \$) & $4(36.4)$ & $7(63.6)$ & 11 & 0.848 \\
\hline $1^{\text {st }}$ pregnancy & $3(37.5)$ & $5(62.5)$ & 8 & \\
Planned & $78(34.4)$ & $149(65.6)$ & 227 & \\
Unplanned & $85(34.6)$ & $161(65.4)$ & 246 & \\
\hline Use contraception before $1^{\text {st }}$ pregnancy & & & \\
Condom & & & \\
Oral pills & & & \\
Depo & & & & \\
\hline Total & & & & \\
\hline
\end{tabular}

Table 2 shows that women with Dalit and Terai caste are more likely to have teenage pregnancy compared to women with other ethnic groups $(\mathrm{P}<0.05)$. The relationship between teenage pregnancy and highest education level of women shows that the teenage pregnancies decreases as education level increases $(\mathrm{p}<0.001)$. Furthermore, economic variable shows stronger association with teenage pregnancies $(\mathrm{p}<0.001)$.

Table 3. Association between birth outcome with age of $1^{\text {st }}$ pregnancy $(\mathrm{N}=246)$

\begin{tabular}{|c|c|c|c|c|}
\hline \multirow[t]{2}{*}{ Characteristics } & \multicolumn{2}{|c|}{ Age of $1^{\text {st }}$ pregnancy } & \multirow[t]{2}{*}{ Total } & \multirow[t]{2}{*}{ P-value } \\
\hline & $<20$ year & $\geq 20$ years & & \\
\hline $\begin{array}{l}\text { Outcome of } 1^{\text {st }} \text { pregnancy } \\
\text { Live } \\
\text { Others (Abortion, still birth) } \\
\text { Presently pregnant }\end{array}$ & $\begin{array}{c}68(31.0) \\
3(27.3) \\
14(87.5) \\
\end{array}$ & $\begin{array}{c}151(69.0) \\
8(72.7) \\
2(12.5)\end{array}$ & $\begin{array}{c}219 \\
11 \\
16\end{array}$ & $<0.001$ \\
\hline $\begin{array}{l}\text { Fetal complications } \\
\text { Yes } \\
\text { No }\end{array}$ & $\begin{array}{l}17(81.0) \\
51(25.8)\end{array}$ & $\begin{array}{c}4(19.0) \\
147(74.2) \\
\end{array}$ & $\begin{array}{c}21 \\
198 \\
\end{array}$ & $<0.001$ \\
\hline $\begin{array}{l}\text { Birth weight of } 1^{\text {st }} \text { baby } \\
<2.5 \mathrm{~kg} \\
2.5-3.5 \mathrm{~kg} \\
>3.5 \mathrm{~kg}\end{array}$ & $\begin{array}{c}18(78.3) \\
46(26.3) \\
4(19.0)\end{array}$ & $\begin{array}{c}5(21.7) \\
129(73.7) \\
17(81.0)\end{array}$ & $\begin{array}{c}23 \\
175 \\
21\end{array}$ & $<0.001$ \\
\hline
\end{tabular}


Fetal complications including birth asphyxia, jaundice, febrile illness and congenital malformations was also higher among them with teenage pregnancy $(\mathrm{p}<0.001)$. The proportion of low birth weight $(<2.5 \mathrm{~kg})$ babies was higher in women with early age pregnancy $(\mathrm{p}<0.001)$.

\section{Discussion}

Globally, 16 million adolescents give birth each year covering $11 \%$ of births worldwide. Ninety five percent of these births occur in low and middle income countries. ${ }^{8}$ The data from 51 countries (from mid 1990s to early 2000) indicated that $10 \%$ girls are already mothers by the age of $16 .{ }^{8}$ Teenage pregnancy is high risk situation for both mother and child because of their vulnerability to many health challenges. ${ }^{9}$ In Nepal, still births and preterm delivery was higher in teenage deliveries compared to births in mature mothers. ${ }^{10}$

This study showed the prevalence of teenage pregnancy (36.4\%) which was similar finding reported in Bangladesh 35\%. ${ }^{11}$ But NDHS (2011) reported that only $17 \%$ of teenage girls had already given birth or were pregnant with their first child. ${ }^{12}$ Similarly the prevalence of teenage pregnancy in Sri Lanka $(8 \%)^{13}$, in India $(21 \%)^{11}$ which were lower than our study.

The relationship between teenage pregnancy and highest education level of women showed that the teenage pregnancies decreases as education level increases $(p<0.001)$.NDHS (2011) also showed that women with SLC or higher education on average begin sexual intercourse four years later than those with no education. Similarly, fertility is also inversely proportional to education level i.e. 3.7 births among those with no education and 1.7 births among women with SLC or higher. ${ }^{12}$ Education plays crucial role in guiding and bringing change in adolescents' behavior. Higher educational attainment, also results in the greater use of Sexual and Reproductive Health (SRH) services, awareness levels. It develops self confidence and decision making power in adolescent girls and helping to delay sexual activities and age of marriages. Educated women can plan for the future, use contraceptives properly, and develop selfesteem. ${ }^{14}$

In this study the economic variable showed stronger association with teenage pregnancies $(p<0.001)$. Evidence from Nepal showed that adolescents from the highest wealth quartile begin sexual intercourse at least two years later than lowest quartile (19.3yrs and 17.1yrs resp.). ${ }^{12}$ Pregnant adolescents are more likely to interrupt education leading less job opportunities (WHO, 2008). The major reasons of interruption to education include the heavy responsibilities of motherhood, a lack of partner, and family support. Inadequate qualifications create difficulties of entering into labor markets and well-paid jobs. Therefore, teenage pregnancy can lead to economic vulnerability. Most of the adolescent mothers in Nepal are living with a high degree of dependence. ${ }^{15}$

Almost $90 \%$ of adolescent girls have an unwanted pregnancy (UN, 2011) ${ }^{16}$ which is higher than our study (46.3\%) of adolescent girls have unplanned pregnancy. Evidences suggests that unwanted teenage pregnancy is associated with violence and sexual coercion. $^{17}$ This is due to economical vulnerability and male reliance. ${ }^{18}$ It is estimated that one out of five pregnant adolescent is suffering from physical abuse worldwide. $^{18,19}$

This study showed $36.4 \%$ of adolescent girl use condom which is lower than the study conducted in the border area of Nepal in which $65 \%$ of adolescent girl used condom 
(Ghubaju, 2002). Worldwide survey on 10,000 teenagers signified, many adolescent girls loosed their virginity in 15 years. Fifty two percent of surveyed teen girls reported they had unprotected sex, and $24 \%$ of adolescent having sexually transmitted infections reported of still having unprotected sex. $^{20}$ Similarly, adolescent do not choose to use a condom with the partners whom they perceive 'clean' because use of it implies a lack of trust and even they do not feel at risk. It could also be interpreted as a sign of having a disease. ${ }^{21} \mathrm{~A}$ study in young factory worker reported $95 \%$ of respondent not using condom. Not feeling pleasurable, unavailability or partners who are not willing to use them may be the main reasons for not using it. ${ }^{22}$

This study showed fetal complications including birth asphyxia, jaundice, febrile illness and congenital malformations was also higher among them with teenage pregnancy $(p<0.001)$. Newborns from teenage pregnancy suffer from many independent adverse effects i.e. fetal distress, birth asphyxia, low birth weight $(\mathrm{LBW}){ }^{23}$ These increase the likelihood of future health problems and the risk of death of baby. ${ }^{24}$ Similarly, it is reported that every four hours, 11 newborn babies die in Nepal, and most of these deaths occur when the mother is an adolescent (DoHS, 2011). Babies born from adolescent mothers are at 50\% higher risk of stillbirth, being premature, and dying during the first month compared to babies from mature mother. $^{15}$

The proportion of low birth weight $(<2.5 \mathrm{~kg})$ babies was higher in women with early age pregnancy $(\mathrm{p}<0.001)$. The study conducted by Chen XK et al also showed that young maternal age is associated with increased risk of low birth weight. ${ }^{25}$ Low birth weight makes a child vulnerable to many diseases (e.g. diabetes, heart disease in near future) and more susceptible to death within one month. Additionally, it can lead to poor health in the future. ${ }^{26}$ Evidence showed that babies from adolescent mothers surveyed later at age 14 showed disturbed psychological behavior, poor reading ability and school performance compared to mature mother children. ${ }^{27}$

\section{Conclusion}

The problem of teenage pregnancy is common and has become a key public health concern for all. Lack of money and education level of men and women was found to be major problem for teenage pregnancy. The result of birth outcome showed that teenage pregnancy was not favourable condition for baby outcome. In order to reduce the teenage pregnancy; adolescents, their parents and community should be made more aware of the negative health, social and economic consequences of it. Such awareness could be created through social mobilization, information dissemination, sex education and communication campaigns. Each and every aspects of teenage pregnancy should ideally be dealt with carefully and sensibly to reduce the occurrence, complications and societal burden of this.

\section{Acknowledgement}

We would like to thank to MBBS (2010 Batch) students who helped us during study period. Our gratitude and sincere thank to participants of Dhankuta Municipality without their support study was not possible and the person who helped us in every way during study period.

\section{References}

1. The WHO study group on young people and health for all by the year 2000. Young people's health a challenge for society. Geneva: World health organization, WHO technical report series No. 731; 1986. 
2. Carter DM, Felice ME, Rosoff J, Zabin LS, Beilenson PL, Dannenberg AL. When children have children: the teen pregnancy predicament. Am J Prev Med 1994; 10: 108-113.

3. Senderowitz J, Paxman JM. Adolescence fertility: Worldwide concern. Population bulletin 1985; 40 (2): 3-51.

4. United Nations. Adolescent reproductive behavior: evidence from developing countries: volume 2. New York: United Nations; 1989.

5. Central Bureau of Statistics. Population census 2001 national report. Kathmandu: National Planning Commission Secretariat and Central Bureau of Statistics- HMG/Nepal in collaboration with UNFPA; 2002.

6. Family Health Division-HMG/ Nepal, New ERA and ORC Macro. Nepal demographic and health survey 2001. Maryland, USA: Family Health Division, HMG/ Nepal, New ERA and ORC Macro; 2002.

7. Ghosh S.Standards of prematurity for north Indian babies. Indian J child Health 1962; 11: 210-215.

8. WHO. Adolescent Pregnancy. MPS Notes, Department of Making Pregnancy safer, Vol 1. No.1, 2008. [Online]. Available from: http://www.who.int/_ maternal_child_ adolescent/documents/mpsnnotes_2_lr.pdf (Accessed May 27, 2013)

9. Singh A. Understanding TEEN Pregnancy, 2012. [Online]. Available from: http:// www.ekantipur.com/2012/06/11/health-andliving/understanding-teen-pregnancy/ 355391.html (Accessed May 27, 2013).

10. Shrestha S. Socio-cultural factors influencing adolescent pregnancy in rural Nepal. International Journal of Adolescent Medicine \& Health 2002; 14:101-109.

11. The World Bank. Children and Youth. The World Bank, Washington DC. 2004; Available from:http://siteresources.worldbank.org/INTCY/D ata/20 333440/YIN-SA. Pdf (Accessed May 27, 2013).

12. Nepal. Department of Health Services (2011). Annual Report. Ministry of Health and Population, Government of Nepal. [Online]. Available from: http://dohs.gov.np/sites/ default/files / 1/files/Annual_Report_2066_67.pdf (Accessed May 27, 2013).

13. Fernando D, Gunawardena N, Senarath U, Weerasinghe $M$, Galwaduge $C$, De Silva $C$. Prevalence, trends and district differentials in teenage pregnancies.Journal of the college of community physicians of Sri Lanka 2011; 16 (2): 21-30.

14. Acharya DR, Teijlingen ERV, Simkhada P. Opportunities and Challenges in school based sex and sexual health education in Nepal. Kathmandu University Medical Journal 2009; 7: 445-453.

15. WHO. Why is giving special attention to adolescent important for achieving Millennium Development Goal? Fact sheet, 2008. [Online]. Available form: http:/ aecid.lac.Unfpa.org/webdav/site/AECID/shared/fil es/Adolescent\%20pregnancy\%20fact\%20sheet.pdf (Accessed May 27, 2013).

16. United Nations, Country team in Nepal (2011). A Country Analysis with a Human Face. [Online]. Available from: http://www.un.org.np/reports/country-analysis2011 (Accessed on May 27, 2013).

17. Glasier A, Glumezogh AM, Schmid GP, Moreno CG, Van PFAL. Sexual and Reproductive Health: A matter of life and death. Lancet 2006; 368 (9547):1595-607.

18. UNFPA. Nepal project document: regional workshop on models for scaling up youth friendly services for SRH \& HIV prevention in South Asia, 12-13 September, 2007. Kathmandu: UNFPA, CST for South and West Asia.

19. WHO. Obstetric Fistula, Guiding principles for clinical management and programme development. Geneva. WHO, 2006. IBSN 9241593679, WHO reference number: WP 180 2006OB. [Online]. Available from: http://www. who.int/ maternal__child_ adolescent/documents/9241593679/en/index.html (Accessed May 27, 2013).

20. Coffey LT. "Survey: Unprotected sex common among teens", TODAY Parenting, 19th November, 2008. [Online]. Available from: http://today.msnbc. msn. Com/id/27706917/?GT1=43001\#.T_18DaZ_PmZ (Accessed May 27, 2013).

21. Marston C, King E. Factors that shape young people's sexual behavior: a systematic review. Lancet 2006; 368 (9547):1581-6.

22. Francoeur RT, Noonan RJ. The Continuum Complete International Encyclopedia of Sexuality: Updated with more countries, 2004. [Online]. Available from: http://www.kinseyinstitute.org/ccies/pdf/cciesnepal.pdf (Accessed May 27, 2013).

23. March of Dimes, PMNCH, Save the Children, WHO. Born Too Soon: The Global Action Report on Preterm Birth. Eds CP Howson, MV Kinney, JE Lawn. World Health Organization (2012) Geneva, IBSN 978924150343 3. [Online]. Available from:http://www.who.int/pmnch/media /news/2012/preterm_birth_ report/en/index. html (Accessed May 27, 2013).

24. WHO. Sexual Health- a new focus for WHO. Progress in Reproductive Health Research. No 67. 
Geneve: WHO, 2004. [Online]. Available from :( http://www.who.

Int/maternal_child_adolescent/topics/maternal/ado lescent_pregnancy/en/index.html) (Accessed May 27, 2013).

25. Chen XK, Wen SW, Fleming N, Demissie K, Rhoads GG, Walker M. Teenage pregnancy and adverse birth outcomes: a large population based retrospective cohort study. Int J Epidemiol 2007; 36(2):368-73.

26. Bellamy C. The progress of nations. The United Nations Childrens Fund (UNICEF), 2000. [Online]. Available from: http://www.unicef.org/ publications/ files/ pub pon2000 en.pdf. (Accessed May 27, 2013).

27. Shaw M, Lawlor DA, Najman JM.Teenage children of teenage mothers: psychological, behavioral, and health outcomes from an Australian prospective longitudinal study. Social Science and Medicine 2006; 62:2526-2539.

Corresponding Address: Dr Ram Bilakshan Sah Assistant Professor, School of Public Health \& Community Medicine B P Koirala Institute of Health Sciences Dharan, Nepal Tel: +977 25 525555-Ext. 3070-Res/5390-Off Mobile: +977-9804012728 Email: bilaksah@yahoo.com 